\title{
Video Article \\ Assessment of Human Natural Killer Cell Events Driven by FcyRIIla Engagement in the Presence of Therapeutic Antibodies
}

\author{
Annalise Petriello ${ }^{1}$, Jacob A. Becerra ${ }^{2}$, Jason Lay ${ }^{1}$, Reem Husaini ${ }^{2}$, Sarah L. Windler ${ }^{1}$, Omar Duramad ${ }^{1}$, Scot D. Liu ${ }^{1}$ \\ ${ }^{1}$ Department of Research and Development, iQ Biosciences \\ ${ }^{2}$ Department of Cellular Products, iQ Biosciences
}

Correspondence to: Scot D. Liu at scot@iqbiosciences.com

URL: https://www.jove.com/video/61144

DOI: doi:10.3791/61144

Keywords: Immunology and Infection, Issue 159, NK cells, FcyRIIla engagement, therapeutic antibodies, small molecules, gene expression, degranulation, cytokine release, signaling

Date Published: 5/22/2020

Citation: Petriello, A., Becerra, J.A., Lay, J., Husaini, R., Windler, S.L., Duramad, O., Liu, S.D. Assessment of Human Natural Killer Cell Events Driven by FcyRllla Engagement in the Presence of Therapeutic Antibodies. J. Vis. Exp. (159), e61144, doi:10.3791/61144 (2020).

\section{Abstract}

One mechanism of action for clinical efficacy by therapeutic antibodies is the promotion of immune-related functions, such as cytokine secretion and cytotoxicity, driven by FcyRIIla (CD16) expressed on natural killer (NK) cells. These observations have led to research focusing on methods to increase Fc receptor-mediated events, which include removal of a fucose moiety found on the Fc portion of the antibody. Further studies have elucidated the mechanistic changes in signaling, cellular processes, and cytotoxic characteristics that increase ADCC activity with afucosylated antibodies. Additionally, other studies have shown the potential benefits of these antibodies in combination with small molecule inhibitors. These experiments demonstrated the molecular and cellular mechanisms underlying the benefits of using afucosylated antibodies in combination settings. Many of these observations were based on an artificial in vitro activation assay in which the FcyRIlla on human NK cells was activated by therapeutic antibodies. This assay provided the flexibility to study downstream effector NK cell functions, such as cytokine production and degranulation. In addition, this assay has been used to interrogate signaling pathways and identify molecules that can be modulated or used as biomarkers. Finally, other therapeutic molecules (i.e., small molecule inhibitors) have been added to the system to provide insights into the combination of these therapeutics with therapeutic antibodies, which is essential in the current clinical space. This manuscript aims to provide a technical foundation for performing this artificial human NK cell activation assay. The protocol demonstrates key steps for cell activation as well as potential downstream applications that range from functional readouts to more mechanistic observations.

\section{Introduction}

Over the last few decades, there has been tremendous focus on developing targeted cancer therapies using antibodies. Therapeutic antibodies, such as trastuzumab and rituximab, operate through multiple mechanisms, including the prevention of dimerization of signaling molecules and mobilization of the immune system ${ }^{1,2}$. The latter is accomplished through antibody-dependent cellular cytotoxicity (ADCC), in which lymphocytes called natural killer (NK) cells are brought to a target cell by the antibody ${ }^{1,2}$. By placing the cells in proximity with each other, the NK cell is activated and can lyse a tumor/target cell through the secretion of effector molecules ${ }^{3}$.

At the molecular level, the Fab portion of the antibody binds its cognate antigen expressed on the tumor cells, while its Fc portion engages the FcyRIIla expressed on NK cells to bring the two cells together ${ }^{1,2}$. After engagement of the FcyRIlla, signaling pathways (i.e., MAPK and PI3K pathways) drive cytoskeletal rearrangement, cytokine production, and cytotoxicity ${ }^{4,5,6,7,8,9}$. Thus, ADCC is an FcyRIlla-driven event mediated by NK cells and antibodies.

Because ADCC was thought to be a mechanism of action for these therapeutic antibodies, researchers searched for methods to increase ADCC by modifying the antibody. One modification was the removal of fucose on the oligosaccharide chain attached to asparagine 297 , which increases the binding affinity of the Fc portion of the antibody to the FcyRIIla ${ }^{10,11,12}$. In animal studies, mice receiving afucosylated antibodies exhibited slower tumor growth compared to mice treated with its fucosylated counterpart ${ }^{13}$. More importantly, obinutuzumab (e.g., Gazyva, an approved afucosylated antibody) showed better efficacy relative to rituximab (e.g., Rituxan, its fucosylated counterpart) in patients diagnosed with chronic lymphocytic leukemia or follicular lymphoma ${ }^{14,15}$

Until recently, the mechanisms underlying increased ADCC via afucosylated antibodies were unknown. Combined with the fact that there are numerous research programs developing therapeutic antibodies to utilize FcyRIlla-driven mechanisms to target cancer cells, it is imperative to develop in vitro assays that examine the molecular and cellular aspects promoted by these antibodies. This provides fundamental understanding of the mechanisms of action as well as the potential to discover biomarkers. As such, an artificial activation assay was developed to study antibody-dependent FcyRIlla-mediated functions in addition to signaling and cellular characteristics ${ }^{8}$. Through these studies, the mechanisms underlying increased efficacy of afucosylated antibodies have been elucidated in which enhanced binding affinity increases signaling to promote cellular properties and cytotoxic characteristics ${ }^{8}$.

The current trend in clinical trials is use of a combination of therapeutic molecules ${ }^{16}$. One of the most commonly mutated pathways is the PI3K pathway, which has prompted tremendous effort in developing small molecule inhibitors that target components of this pathway ${ }^{17,18,19,20}$. Yet, how 
these molecules act in combination with therapeutic antibodies is relatively unknown, especially in combinations where the inhibitor may affect molecules that require the $\mathrm{PI} 3 \mathrm{~K}$ pathway in order to function, such as those driven by therapeutic antibodies.

To this end, the in vitro assay employed for the afucosylated antibody studies has also been used to study the combination of PI3K inhibitors and therapeutic antibodies. These studies defined the molecular characteristics of PI3K inhibition on therapeutic antibody PI3K-driven events and described how afucosylated antibodies can offset this loss of signaling ${ }^{9}$. These findings are relevant as they lend potential guidance for designing clinical trials. In addition, this series of experiments also led to the first described observations for kinetic regulation of the $\mathrm{PI} 3 \mathrm{~K}$ signaling pathway to modulate chemokine/cytokine transcription and production, which may serve as potential biomarkers ${ }^{9}$.

The artificial in vitro activation assay used to define the signaling and cellular characteristics described above has been designed to study FcyRIIla-driven events in NK cells mediated by antibodies in the absence of target cells. Without target cells in the system, all of the signaling events and functions observed can be attributed directly to the NK cells. In the presented assay, antibody is added to purified NK cells, at which point the Fc portion binds the FcyRIIla. This is followed by crosslinking of the antibody using an anti-human $\mathrm{k}$ light chain antibody to artificially stimulate the cells. Crosslinking of the antibody mimics binding of the target antigen to generate a signaling platform that elicits downstream events. Depending on the length of stimulation, researchers can assess signaling, cellular processes, cytotoxic characteristics, and effector functions ${ }^{8,9}$. Similarly, this assay also provides flexibility in studying these events when antibodies are combined with other molecules ${ }^{9}$.

Together, this is an ideal in vitro assay to study therapeutic antibodies that elicit NK cell responses through their FcyRIIla as part of the mechanism of action. This protocol describes the performance of this in vitro activation assay and provides insight into the various readouts that can be performed.

\section{Protocol}

The following protocol is in accordance with the guidelines of iQ Bioscience's human research ethics committee.

\section{Isolation of PBMCs and enrichment/purification of NK cells}

NOTE: Other methods for the isolation of peripheral blood mononuclear cells (PBMCs) and enrichment/purification can also be performed.

1. Draw $200 \mathrm{~mL}$ of blood under regulated conditions into a tube containing heparin.

2. Add $15 \mathrm{~mL}$ of the density gradient medium into a $50 \mathrm{~mL}$ tube with a porous barrier incorporated. Spin the tube at $1000 \times \mathrm{g}$ for $30 \mathrm{~s}$.

3. Add $12.5 \mathrm{~mL}$ of blood into the tube followed by another $12.5 \mathrm{~mL}$ of PBS, and gently invert $3 \mathrm{x}$. Spin the tube at $800 \times \mathrm{g}$ for $15 \mathrm{~min}$ at room temperature (RT) with no breaks.

4. Prepare a $50 \mathrm{~mL}$ conical tube with $40 \mathrm{~mL}$ of PBS for each tube with a porous barrier while the cells are spinning

5. Carefully remove the tubes and inspect after centrifugation. Check for a thin, visibly white layer of PBMCs above the porous barrier, between the $20 \mathrm{~mL}$ and $25 \mathrm{~mL}$ demarcations on the $50 \mathrm{~mL}$ tube.

6. Carefully remove as much liquid as possible from the top using a pipette without disturbing the thin, white PBMC layer.

7. With a clean $10 \mathrm{~mL}$ serological pipette, gently remove the PBMC layer in addition to the clear, yellowish liquid layer down to the filter of the tube.

8. Expel the PBMCs and liquid into the $50 \mathrm{~mL}$ conical containing PBS prepared in step 1.4. Spin tubes at RT and $300 \times g$ for $5 \mathrm{~min}$.

9. Aspirate the PBS wash and add an additional $40 \mathrm{~mL}$ of PBS. Spin tubes at RT and $300 \times \mathrm{g}$ for $5 \mathrm{~min}$.

10. After washing, count the cells and resuspend them in $40 \mu \mathrm{L}$ of $2 \%$ BSA/PBS per $1 \times 10^{7}$ cells.

11. Proceed to the isolation of NK cells using the method of choice. Choices include manual or automated magnetic bead-based sorting ${ }^{9,21}$. Fluorescence-activated cell sorting can also be performed ${ }^{22}$.

12. Remove a small aliquot of cells to determine the purity of NK cells by flow cytometry. Gating strategy includes the following: gate on live cells based on forward vs. side scatter profile, then assess the purity based on NK markers (e.g., CD3, CD56) in the specific live population. Typical purity is $>95 \%$.

13. After isolation is completed, spin cells at RT and $300 \times \mathrm{g}$ for $5 \mathrm{~min}$ to pellet and aspirate.

14. Resuspend the cell pellet to $1 \times 10^{7}$ cells/mL in RPMI 1640 with nutrients, $10 \%$ heat-inactivated FBS, $1 \mathrm{mM}$ sodium pyruvate, $55 \mathrm{mM} 2-\mathrm{ME}$, and $10 \mathrm{mM}$ HEPES $(\mathrm{pH}=7.2)$.

\section{Antibody-mediated activation of NK cells via FcyRIlla}

1. Set a refrigerated microcentrifuge to $4{ }^{\circ} \mathrm{C}$

2. Dispense $1 \times 10^{6}(100 \mu \mathrm{L}$ of) resuspended NK cells into $1.5 \mathrm{~mL}$ tube(s) and place on ice. NOTE: Cells can be dispensed into a 96 well U-bottom plate if there are numerous samples.

3. Prepare $1 \mu \mathrm{L}$ of $100 \mu \mathrm{g} / \mathrm{mL}$ rituximab (or antibody of interest) per sample and add $1 \mu \mathrm{L}$ to the cells for a final concentration of $1 \mu \mathrm{g} / \mathrm{mL}$ antibody.

NOTE: Other molecules can be added to the cells at this point or earlier for the assessment of combination effects. Here, ritixumab was used for stimulation. In prior studies, small molecule inhibitors have been added to stimulations 9 .

4. Incubate the sample on ice for $30 \mathrm{~min}$. During incubation, prepare $50 \mu \mathrm{L}$ of $50 \mu \mathrm{g} / \mathrm{mL}$ anti-human $\mathrm{k}$ light chain antibody per sample in media and warm to $37^{\circ} \mathrm{C}$ on a heat block or in a water bath.

5. After incubation of cells on ice, add $1 \mathrm{~mL}$ of ice-cold media and spin at $135 \mathrm{xg}$ for $5 \mathrm{~min}$ at $4{ }^{\circ} \mathrm{C}$. Wash again with $1 \mathrm{~mL}$ of ice cold-media.

6. Aspirate the supernatant after the last wash and add $50 \mu \mathrm{L}$ of the anti-human $\mathrm{K}$ light chain mixture prepared in step 2.5 .

7. Immediately incubate samples for the end-user determined timepoints at $37^{\circ} \mathrm{C}$ on a heat block or in a water bath.

8. Stop stimulation by adding $1 \mathrm{~mL}$ of ice-cold media and immediately spin samples in a refrigerated centrifuge at $135 \times \mathrm{g}$ for $5 \mathrm{~min}$. Wash once more with $1 \mathrm{~mL}$ of ice-cold media. 


\section{Downstream applications and readouts}

1. Interrogation of signaling molecules in FcyRIIla-stimulated NK cells by western blot analysis

NOTE: Different protein separation and membrane transfer apparatuses may be used.

1. After the last washing with ice-cold media (step 2.8), lyse cells with $20 \mu \mathrm{L}$ of RIPA buffer containing phosphatase and protease inhibitors mix for $30 \mathrm{~min}$ on ice.

2. Spin tubes at $2100 \times \mathrm{g}$ for $15 \mathrm{~min}$ at $4{ }^{\circ} \mathrm{C}$. Transfer the lysate to a clean $1.5 \mathrm{~mL}$ tube and add the reagents required for protein separation.

3. Separate proteins on SDS-PAGE gel and transfer onto a nitrocellulose or PVDF membrane following standard protocols.

4. Block and probe the membrane according to the manufacturer's datasheet for the primary detection antibody (here, pAKT, pPRAS 40, and $\mathrm{pERK} 1 / 2$ were used).

5. Add HRP conjugated secondary antibody and chemiluminescence reagent per the manufacturer's recommendations on the PVDF membrane. Use X-ray film or detection instrument to visualize (here, pAKT was detected at $60 \mathrm{kDa}, \mathrm{pPRAS} 40$ at $40 \mathrm{kDa}$, and pERK1/2 at $42 \mathrm{kDa}$ and $44 \mathrm{kDa})$.

2. Isolation of mRNA and preparation for gene expression analysis of FcyRIlla-stimulated NK cells (Table of Materials)

1. After the timepoint for stimulation is reached (step 2.7), place the tube on ice and immediately spin in a refrigerated centrifuge at $135 \mathrm{x}$ $g$ for 5 min (similar to step 2.8).

2. Remove the supernatant and wash $2 x$ with $1 \mathrm{~mL}$ of ice-cold PBS.

3. Lyse cells using guanidium isothiocyanate RNA extraction (Table of Materials). Use $1 \mu \mathrm{g}$ of mRNA to perform reverse transcription using random hexamers with a commercial kit (Table of Materials).

NOTE: Any method of RNA extraction or cDNA synthesis can be used ${ }^{9,23,24}$

4. Freeze cDNA at $-20{ }^{\circ} \mathrm{C}$ until gene expression analysis.

3. Cytoskeletal rearrangement assessment in FcyRIIla-stimulated NK cells

1. After the last washing with ice-cold media (step 2.8), resuspend the cell pellet with $50 \mu \mathrm{L}$ of $3.7 \%$ paraformaldehyde for 10 min at RT.

2. Add $1 \mathrm{~mL}$ of PBS and spin at $135 \times \mathrm{g}$ for $5 \mathrm{~min}$ at RT. Repeat this washing once more.

3. Add $100 \mu \mathrm{L}$ of $0.1 \%$ Triton X-100/PBS for $5 \mathrm{~min}$ to permeabilize cells, and spin cells at $135 \times \mathrm{g}$ for $5 \mathrm{~min}$ at RT to pellet.

4. Add $100 \mu \mathrm{L}$ of 5 units/mL AF488-labeled phalloidin diluted in $1 \%$ BSA/PBS and incubate for $20 \mathrm{~min}$ at RT.

5. Add $1 \mathrm{~mL}$ of PBS and spin at $135 \times \mathrm{g}$ for $5 \mathrm{~min}$ at RT to wash. Resuspend the cell pellet in the desired volume for flow cytometric analysis.

4. Assessing degranulation of FcyRIlla-stimulated NK cells using CD107a surface staining

1. Incubate the cells with the antibody of interest on ice as described in steps 2.1-2.4. During incubation, prepare $50 \mu \mathrm{L}$ of antibody mixture per sample. Prepare the mixture in cell media with a final concentration of $50 \mu \mathrm{g} / \mathrm{mL}$ anti-human $\mathrm{k}$ light chain antibody and 1 $\mu \mathrm{g} / \mathrm{mL}$ fluorochrome-labeled CD107a.

2. After incubation of the cells on ice, add $1 \mathrm{~mL}$ of ice-cold media. Spin at $135 \times \mathrm{g}$ for $5 \mathrm{~min}$ at $4{ }^{\circ} \mathrm{C}$, then wash again with $1 \mathrm{~mL}$ of ice coldmedia.

3. Aspirate the supernatant after the last washing, then add $50 \mu \mathrm{L}$ of the anti-human $\mathrm{k}$ light chain mixture and incubate at $37^{\circ} \mathrm{C}$ for the desired timepoints.

4. At the desired timepoints, add $1 \mathrm{~mL}$ of PBS and spin at $135 \times \mathrm{g}$ for $5 \mathrm{~min}$ at RT. Aspirate supernatant and add $100 \mu \mathrm{L}$ of $4 \%$ paraformaldehyde. Incubate at RT for $10 \mathrm{~min}$.

5. Add $1 \mathrm{~mL}$ of PBS and spin at $135 \times \mathrm{g}$ for $5 \mathrm{~min}$ at RT to wash. Resuspend the cell pellet in the desired volume for flow cytometric analysis.

5. Assessment of chemokine/cytokine production from FcyRIlla-stimulated NK cells

NOTE: Different methods and/or kits may be used for assessment of chemokine and cytokine production.

1. After the timepoint for stimulation is reached (step 2.7), immediately place the tube on ice and spin in a refrigerated centrifuge at $135 \mathrm{x}$ $\mathrm{g}$ for $5 \mathrm{~min}$ at $4{ }^{\circ} \mathrm{C}$.

2. Transfer the supernatant into a clean vessel. Freeze the supernatant until chemokine or cytokine assessment using the desired assay. NOTE: Cell pellets can now be washed with ice-cold PBS and processed for signaling, gene expression, and cytoskeletal rearrangement studies.

\section{Representative Results}

It is essential that NK cell purity is high because the Fc portion of antibodies can bind the FcyRIlla expressed on other cell types, such as monocytes. With high purity, the observations made can be attributed directly to FcyRIlla-driven events in NK cells. Here, NK cells had greater than $90 \%$ purity based on CD56 and CD3 stains (Figure 1). In addition, the viability was $>95 \%$. Care should be used when using isolations with lower viability. To ensure events were driven by the FcyRIlla, western blots for phospho-AKT (pAKT), phospho-PRAS40 (pPRAS40), and phospho-ERK1/2 (pERK1/2) were performed, in which NK cells were activated for 1-5 min. As shown, an accumulation of these molecules was observed (Figure 2). Similarly, activated NK cells expressed MIP-1 $\alpha$, MIP-1 $\beta$, IFN- $\gamma$, and TNF- $\alpha$, as shown by gene expression analysis (Figure 3).

Additionally, cytoskeletal rearrangement was observed in activated cells (Figure 4). A percentage of NK cells stimulated for $4 \mathrm{~h}$ expressed CD107a on the cell surface (Figure 5). Additionally, IFN- $\gamma$, TNF- $\alpha$, MIP-1 $\alpha$, MIP-1 $\beta$, and RANTES were detected in the supernatant after $3 \mathrm{~h}$ of stimulation (Figure 6). These readouts are expected based on published studies as activated NK cells will have these phosphorylated proteins, as well as the gene expression and production of the mentioned chemokines and cytokines ${ }^{8,9}$. In all experiments, stimulation conditions should 
include an anti-human $\mathrm{k}$ light chain only control and antibody without anti-human $\mathrm{k}$ light crosslinking control. These NK cells should not show any phospho-signaling, degranulation, chemokine/cytokine production, or chemokine/cytokine gene expression.

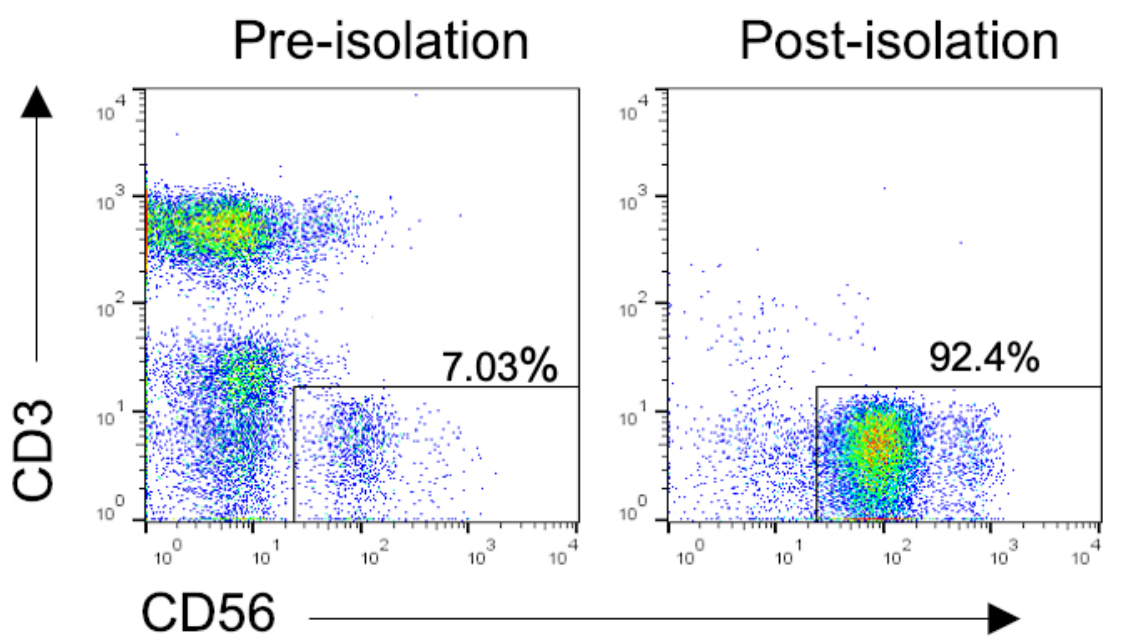

Figure 1: Representative flow profiles of NK cell purity after isolation from PBMCs. PBMCs were isolated from blood of a healthy donor, followed by enrichment of NK cells using a negative selection method for human NK cell isolation (Table of Materials). Cells were stained with CD56 and CD3 before and after enrichment to determine purity. Representative dot plots of CD56 vs. CD3 before and after isolation. Please click here to view a larger version of this figure.

\section{2 min stim}

\section{Anti-human k light chain antibody $\quad-\quad+$}

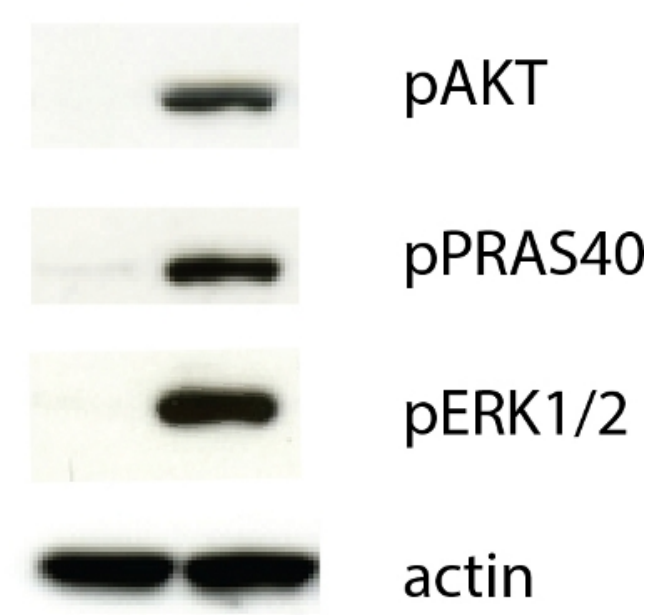

Figure 2: FcyRIlla-activated NK cells exhibit phosphorylated signaling molecules. Cells were stimulated with rituximab for 2 min, and cell lysates were made according to the protocol. Lysates were separated on a $4 \%-12 \%$ gel, followed by transfer onto a PVDF membrane. The membrane was probed with antibodies against pAKT, pPRAS40, pERK1/2, and actin. Please click here to view a larger version of this figure. 
A.

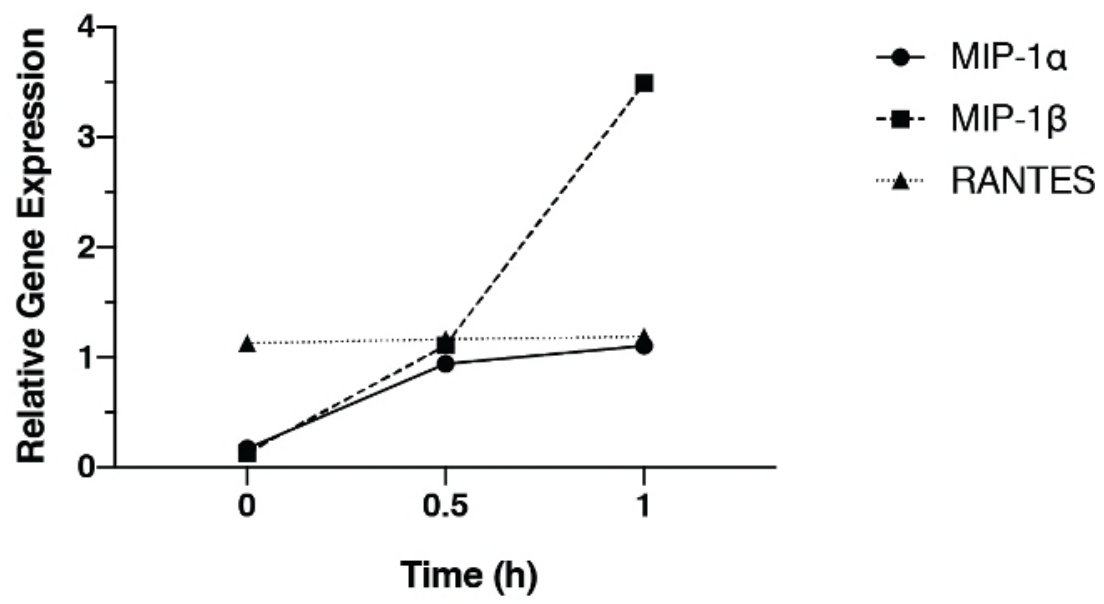

B.

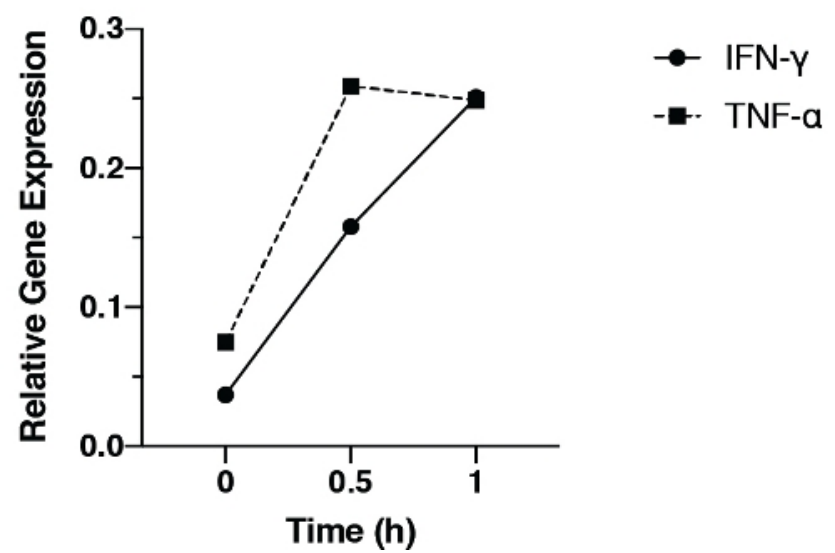

Figure 3: FcyRIlla-activated NK cells express chemokine and cytokine genes. NK cells were stimulated with rituximab for $0 \mathrm{~h}, 0.5 \mathrm{~h}$, and $1 \mathrm{~h}$. mRNA was collected, reverse-transcribed, and subjected to QPCR analysis for MIP-1 $\alpha$, MIP-1 $\beta$, RANTES, IFN- $\gamma$, and TNF- $\alpha$ (Table of Materials). (A) Relative expression of MIP-1 $\alpha$, MIP-1 $\beta$, and RANTES at each timepoint. (B) Relative expression of IFN- $\gamma$ and TNF- $\alpha$ at each timepoint. Values were normalized to the actin gene. Please click here to view a larger version of this figure. 


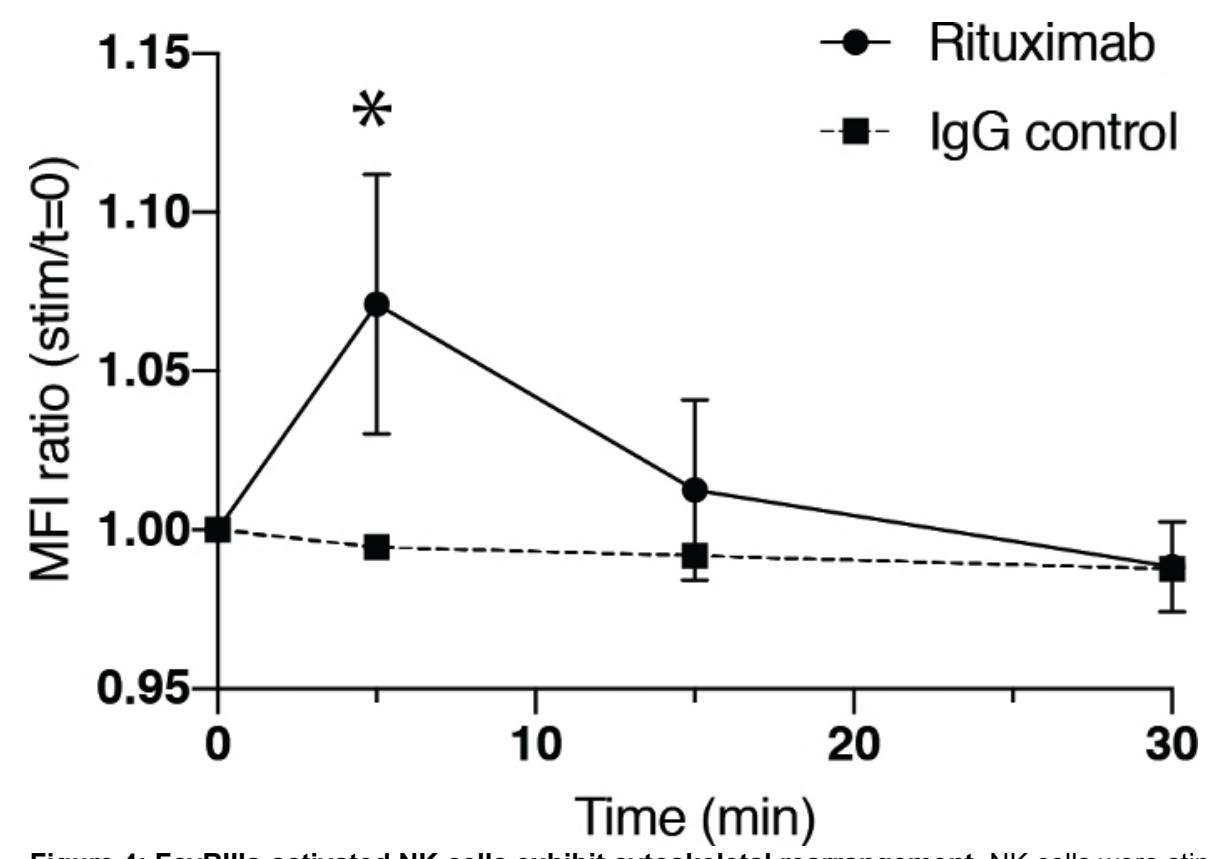

Figure 4: FcyRIIla-activated NK cells exhibit cytoskeletal rearrangement. NK cells were stimulated with rituximab for 0 min, 5 min, 15 min, and $30 \mathrm{~min}$, followed by assessment for cytoskeletal rearrangement by phalloidin staining and flow cytometry. The ratio of MFI at experimental timepoint to the MFI at time 0 of NK cells stimulated with rituximab (circle, solid line) or secondary antibody alone (square, dotted line). Bars represent the SD of four replicates. Asterisks represent statistical significance based on a two-tailed unpaired Student's t-test ( $\left.{ }^{*} p<0.05\right)$. Please click here to view a larger version of this figure.

A.

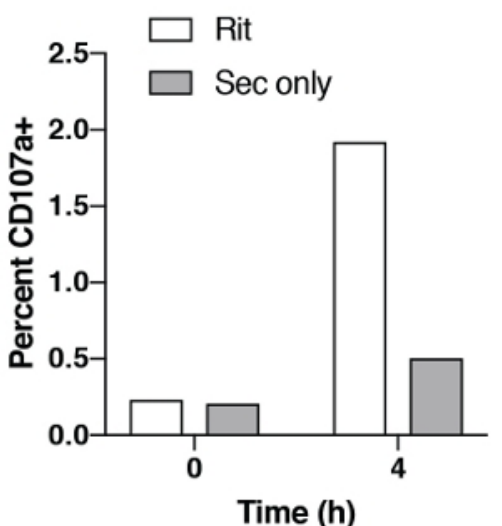

B.

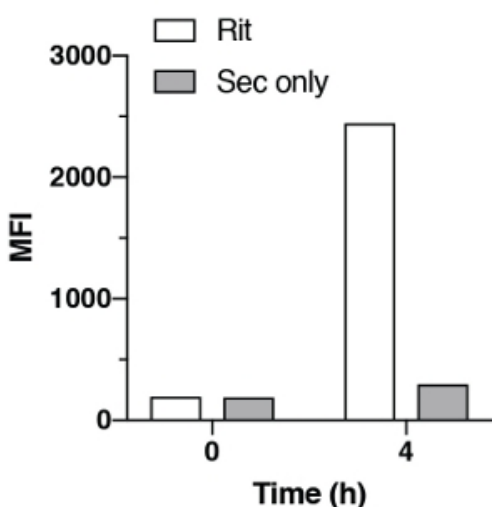

Figure 5: FcyRIIla-activated NK cells express CD107a. NK cells were stimulated with rituximab for $4 \mathrm{~h}$ followed by assessment for degranulation by CD107a and flow cytometry. (A) Percentage of NK cells expressing CD107a after stimulation with rituximab (white bars) or antihuman $\mathrm{k}$ light chain antibody (gray bars) for $0 \mathrm{~h}$ and $4 \mathrm{~h}$. (B) CD107a MFI of NK cells stimulated with rituximab (white bars) or anti-human $\mathrm{k}$ light chain antibody (gray bars) after $0 \mathrm{~h}$ and $4 \mathrm{~h}$ of treatment. Please click here to view a larger version of this figure. 
A.

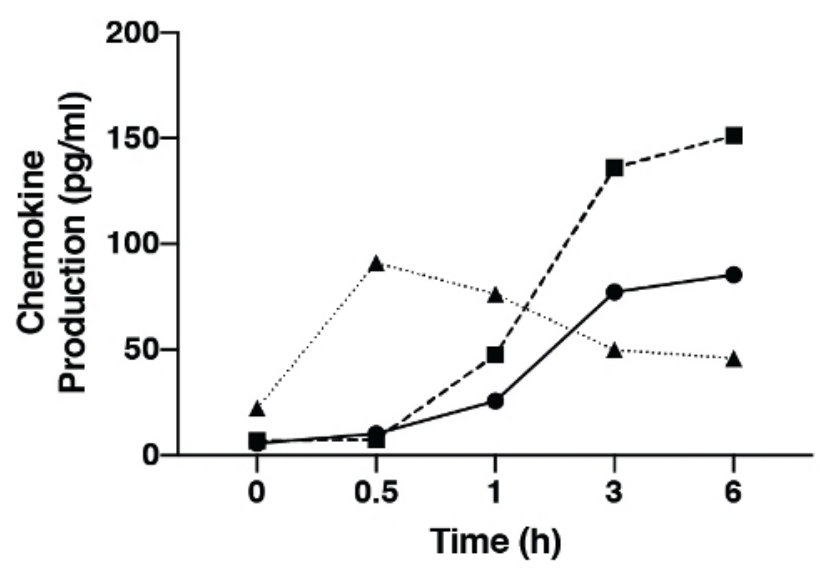

- MIP-1a
- MIP-1 $\beta$
- RANTES

B.

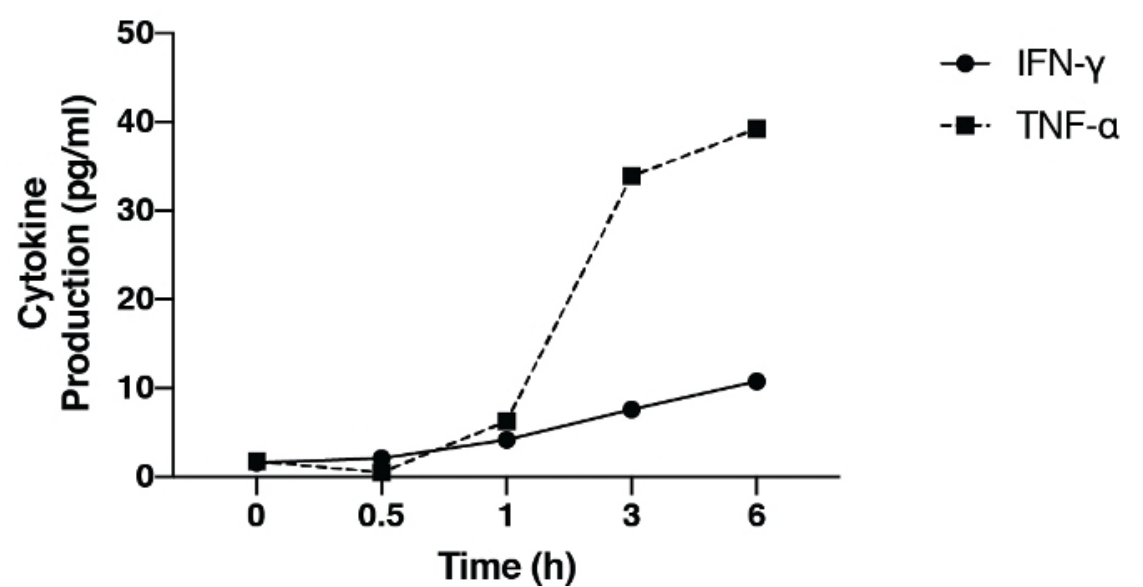

Figure 6: FcyRIlla-activated NK cells secrete chemokines and cytokines. NK cells were stimulated for $0,0.5,1,3$, and 6 hr with rituximab. Supernatant was collected to measure release of MIP-1 $\alpha$, MIP-1 $\beta$, RANTES, IFN- $\gamma$, and TNF- $\alpha$ by a flow- and bead-based cytokine assessment method (Table of Materials). (A) MIP-1 $\alpha$, MIP-1 $\beta$, and RANTES production at each timepoint. (B) IFN- $\gamma$ and TNF- $\alpha$ production at each timepoint. Please click here to view a larger version of this figure.

\section{Discussion}

This protocol describes methods for studying FcyRIlla-driven events in NK cells mediated by antibodies. These techniques permit the evaluation of potential mechanisms of action of therapeutic antibodies, which is suggested to be ADCC ${ }^{1,2}$. Specifically, these methods provide flexibility in studying underlying molecular signaling pathways and cellular processes that are responsible for ADCC. They also allow observation of other effector functions, such as chemokine and cytokine production. In addition, these methods allow the identification of potential biomarkers and molecules that may be targeted to modulate ADCC.

The basis for this protocol is the artificial stimulation of NK cells through the FcyRIlla with antibodies in the absence of target cells. Antibodybound target cells typically serve to promote the crosslinking of Fc receptors to form a platform that drives signaling and downstream effects. Instead, crosslinking is accomplished using an anti-human $\mathrm{K}$ light chain antibody in this assay, bypassing the need for target cells to stimulate the NK cells. Without target cells, the results and observations can be attributed directly to the NK cells, assuming that the purification process is successful.

Importantly, using anti-human $\mathrm{k}$ light chain antibody to crosslink the antibody does not interfere with the binding affinity of the Fc portion for the FcyRIIla, an interaction that dictates the strength of response ${ }^{10,11,12,13}$. Indeed, studies have shown that afucosylated antibodies increase ADCC due to their increased affinity for the FcyRIIIa ${ }^{10,11,12,13}$. Subsequent studies showed that this increased affinity is unaffected by the anti-human $\mathrm{K}$ light chain secondary antibody substitute and can be used to study the basis for increased ADCC ${ }^{8}$. To ensure that the NK cell is stimulated through crosslinking of the antibody, two negative controls should be included: 1) therapeutic antibody only without the secondary anti-human $\mathrm{K}$ light chain antibody, and 2) the secondary anti-human $\mathrm{K}$ light chain antibody only. In both cases, no signaling or effector function should be generated. 
This method also provides flexibility for studying the effects of therapeutic antibodies on small molecule inhibitors. The inhibitor can be added before crosslinking with the secondary antibody so that the inhibitor has time to engage its target. However, studies should be performed to determine the optimal time of inhibitor pretreatment; thus, the inhibitor has a maximal effect on stimulation. With that said, researchers may also choose to study the effects of an inhibitor after stimulation. In this case, the inhibitor may be added after crosslinking to study how it influences signals and processes that are already generated. Together, the method described here provides maximal flexibility in studying combinatorial effects of different small molecule inhibitors with therapeutic antibodies.

As mentioned above, a variety of readouts can be performed after stimulation. Western blotting can be performed to study signaling using SDSPAGE and membrane transfer systems from various vendors. Similarly, gene expression can also be assessed using various RNA extraction methods, reverse transcription reagents, and gene expression instruments. Finally, staining for intracellular or extracellular protein can also be performed in which samples can be analyzed using different flow cytometers. For intracellular cytokine and CD107a staining (step 3.4, which can be assessed simultaneously), monensin and/or brefeldin A should be added to maximize signals. We have used different platforms for each experimental goal and still observed similar results. Therefore, the method can be complemented with various reagents, platforms, and instruments, depending on the study.

The crosslinking time for stimulation will depend on the goal of the study. If signaling studies are desired, typical crosslinking stimulation time is between $2 \mathrm{~min}$ and $10 \mathrm{~min}$. pAKT, pPRAS40, and pERK1/2 accumulation peaks at 2 min and disappears after 10 min $^{8,9}$. For functional studies (i.e., those involving chemokine/cytokine production), cells must be stimulated for at least 30 min, depending on the analyte ${ }^{9}$. Gene expression analysis also typically requires $30 \mathrm{~min}$ of stimulation ${ }^{9}$. Caution should be exercised when using RANTES gene expression as a readout, as RANTES mRNA production is independent of transcriptional activation since it is already stored in cells for prompt translation and release of protein upon stimulation ${ }^{25}$. Degranulation, in contrast, requires at least $3 \mathrm{~h}$ of stimulation. Despite these general observations, researchers should perform kinetic studies to determine the optimal stimulation time for the particular molecules of interest.

Similarly, researchers should titrate the antibody of interest to determine the optimal concentration because antibodies with different specificities bind to FcyRIlla with different affinities, even if they are of the same isotype. For example, rituximab and trastuzumab are both an IgG1 isotype but trastuzumab binds more strongly to the valine polymorphism of FcyRIlla than rituximab ${ }^{26,27}$. This difference in affinity may lead to functional differences, such as degranulation, as observed in published studies ${ }^{8}$.

Determining the optimal concentration is also important because of the low affinity the Fc portion of the antibody has for the FcyRIlla. This may result in washing off the antibody since the protocol includes washing steps after binding of the antibody to the Fc receptor. This may then lead to a lack of sensitivity in the assays as suggested by the low percentage of CD107a positive cells after stimulation (Figure 5). However, determination of the optimal concentration should provide confidence that results are not due to a lack of sensitivity. In addition, cells are clearly activated in the biochemical and functional assays that use bulk cell as opposed to single cell readouts (Figure 2, Figure 3, Figure 6).

The protocol is also limited since it does not entirely mimic what occurs physiologically. The secondary anti-human $\mathrm{K}$ antibody used is to imitate the crosslinking generated by target antigen expressed on cells. Here, a saturating amount of secondary antibody is added to generate the maximum response. However, distinct target cells will express different levels of antigen, which will affect crosslinking and response. Currently, this platform is not optimized to mimic the effects of different antigen expression levels.

Another factor to consider when performing these experiments is donor-to-donor variability due to different genetic backgrounds and immunological histories among individuals. Therefore, care must be taken when comparing NK cell responses from different donors across the same assays. Similarly, only general conclusions should be made when different donors are used.

Altogether, the described method is a simple and flexible stimulation platform to study antibody driven FcyRIIla-mediated events in NK cells. It has been used to better understand the basis for the increased ADCC and efficacy observed with afucosylated antibodies ${ }^{8}$. This method was also employed in a study combining therapeutic antibodies and PI3K small molecule inhibitors ${ }^{9}$. Additionally, a previously unknown mechanism for chemokine and cytokine production regulated by pS6 was identified ${ }^{9}$. Therefore, future studies using this artificial signaling platform can further elucidate mechanisms of regulation for effector functions driven by the FcyRIIla. It may also potentially identify new molecules important for these mechanisms as well as new roles for known molecules.

\section{Disclosures}

All authors are or have been employees or consultants for iQ Biosciences.

\section{Acknowledgments}

The authors thank James Lee and Christopher $\mathrm{Ng}$ for comments and editing of this manuscript.

\section{References}

1. Hudis, C. A. Trastuzumab - Mechanism of Action and Use in Clinical Practice. New England Journal of Medicine. 357 (1), $39-51$ (2007).

2. Weiner, G. J. Rituximab: mechanism of action. Seminars inHhematology. 47 (2), 115-123 (2010).

3. Orange, J. S. Formation and function of the lytic NK-cell immunological synapse. Nature Reviews Immunology. 8 (9), $713-725$ (2008).

4. Bonnema, J. D., Karnitz, L. M., Schoon, R. A., Abraham, R. T., Leibson, P. J. Fc receptor stimulation of phosphatidylinositol 3-kinase in natural killer cells is associated with protein kinase C-independent granule release and cell-mediated cytotoxicity. The Journal of Experimental Medicine. 180 (4), 1427-1435 (1994).

5. Jiang, K. et al. Pivotal role of phosphoinositide-3 kinase in regulation of cytotoxicity in natural killer cells. Nature Immunology. 1 (5), $419-425$ (2000). 
6. Kanakaraj, P. et al. Phosphatidylinositol-3 kinase activation induced upon Fc gamma RIIIA-ligand interaction. The Journal of Experimental Medicine. 179 (2), 551-558 (1994).

7. Orange, J. S., Harris, K. E., Andzelm, M. M., Valter, M. M., Geha, R. S., Strominger, J. L. The mature activating natural killer cell immunologic synapse is formed in distinct stages. Proceedings of the National Academy of Sciences. 100 (24), 14151-14156 (2003).

8. Liu, S. D. et al. Afucosylated Antibodies Increase Activation of FcyRllla-Dependent Signaling Components to Intensify Processes Promoting ADCC. Cancer Immunology Research. 3 (2), 173-183 (2015).

9. Romeo, V., Gierke, S., Edgar, K. A., Liu, S. D. Effects of PI3K Inhibition on Afucosylated Antibody-Driven FcyRIlla Events and Phospho-S6 Activity in NK Cells. The Journal of Immunology. 203 (1), 137-147 (2019).

10. Mössner, E. et al. Increasing the efficacy of CD20 antibody therapy through the engineering of a new type II anti-CD20 antibody with enhanced direct and immune effector cell-mediated B-cell cytotoxicity. Blood. 115 (22), 4393-4402 (2010).

11. Shields, R. L. et al. Lack of fucose on human IgG1 N-linked oligosaccharide improves binding to human Fcgamma RIII and antibodydependent cellular toxicity. The Journal of Biological Chemistry. 277 (30), 26733-26740 (2002).

12. Shinkawa, T. et al. The absence of fucose but not the presence of galactose or bisecting N-acetylglucosamine of human IgG1 complex-type oligosaccharides shows the critical role of enhancing antibody-dependent cellular cytotoxicity. The Journal of Biological Chemistry. 278 (5), 3466-3473 (2003).

13. Junttila, T. T. et al. Superior In vivo Efficacy of Afucosylated Trastuzumab in the Treatment of HER2-Amplified Breast Cancer. Cancer Research. 70 (11), 4481-4489 (2010).

14. Goede, V. et al. Obinutuzumab (GA101) plus chlorambucil $(\mathrm{Clb})$ or rituximab $(\mathrm{R})$ plus $\mathrm{Clb}$ versus $\mathrm{Clb}$ alone in patients with chronic lymphocytic leukemia (CLL) and preexisting medical conditions (comorbidities): Final stage 1 results of the CLL11 (BO21004) phase III trial. Journal of Clinical Oncology. 31 (15_suppl), 7004-7004 (2013).

15. Sehn, L. H. et al. Randomized Phase II Trial Comparing Obinutuzumab (GA101) With Rituximab in Patients with Relapsed CD20+ Indolent BCell Non-Hodgkin Lymphoma: Final Analysis of the GAUSS Study. Journal of Clinical Oncology. 33 (30), 3467-3474 (2015).

16. Pons-Tostivint, E., Thibault, B., Guillermet-Guibert, J. Targeting PI3K Signaling in Combination Cancer Therapy. Trends in Cancer. 3 (6), 454-469 (2017).

17. Engelman, J. A. Targeting PI3K signalling in cancer: opportunities, challenges and limitations. Nature Reviews. Cancer. 9 (8), $550-562$ (2009).

18. Fruman, D. A., Rommel, C. PI3K and cancer: lessons, challenges and opportunities. Nature Reviews. Drug Discovery. 13 (2), $140-156$ (2014).

19. Janku, F., Yap, T. A., Meric-Bernstam, F. Targeting the PI3K pathway in cancer: are we making headway? Nature Reviews. Clinical Oncology. 15 (5), 273-291 (2018).

20. Samuels, Y. et al. High frequency of mutations of the PIK3CA gene in human cancers. Science (New York, N.Y.). 304 (5670), 554 (2004).

21. Kanevskiy, L. M., Telford, W. G., Sapozhnikov, A. M., Kovalenko, E. I. Lipopolysaccharide induces IFN-y production in human NK cells. Frontiers in Immunology. 4, (2013).

22. Romagnani, C. et al. Activation of human NK cells by plasmacytoid dendritic cells and its modulation by CD4+ T helper cells and CD4+ CD25hi T regulatory cells. European Journal of Immunology. 35 (8), 2452-2458 (2005).

23. Sivori, S. et al. CpG and double-stranded RNA trigger human NK cells by Toll-like receptors: Induction of cytokine release and cytotoxicity against tumors and dendritic cells. Proceedings of the National Academy of Sciences. 101 (27), 10116-10121 (2004).

24. Hanna, J. et al. Novel Insights on Human NK Cells' Immunological Modalities Revealed by Gene Expression Profiling. The Journal of Immunology. 173 (11), 6547-6563 (2004).

25. Swanson, B. J., Murakami, M., Mitchell, T. C., Kappler, J., Marrack, P. RANTES production by memory phenotype T cells is controlled by a posttranscriptional, TCR-dependent process. Immunity. 17 (5), 605-615 (2002).

26. Jo, M., Kwon, H. S., Lee, K.H., Lee, J. C., Jung, S. T. Engineered aglycosylated full-length IgG Fc variants exhibiting improved FcyRIIla binding and tumor cell clearance. mAbs. 10 (2), 278-289 (2018).

27. Isoda, Y. et al. Importance of the Side Chain at Position 296 of Antibody Fc in Interactions with FcyRIIla and Other Fcy Receptors. PLoS ONE. 10 (10), e0140120 (2015). 